\title{
Relationship of Intellectual Intelligence Level With High School Basketball Shooting Ability
}

\author{
Hasriwandi Nur*, Freno Celvin Pradana \\ Sport Education Program \\ Faculty of Sport Science \\ Padang State University \\ Padang, Indonesia \\ haswanhambaallah@gmail.com
}

\begin{abstract}
The problem in this research is the lack of freethrow shooting capability of high school students at the Laboratory Development at Padang State University, which is allegedly due to the lack of students' intellectual intelligence. The purpose of this study is to look at the relationship of the level of intellectual intelligence with the ability to shoot free throw basketball for students who take extracurricular activities at the SMA Negeri Laboratory of Padang Development High School in 2018. Based on the results of data analysis, there is a significant relationship between the level of Intellectual Intelligence with Shooting Ability in High School Extracurricular Basketball UNP Laboratory Development Students, where $r$ count $=$ $0.775 \alpha$ This type of research is correlational. The population and sample in this study were all basketball high school UNP Laboratory development totaling 26 people with a total sampling technique. Data collection techniques for students' intellectual intelligence levels and shooting abilities were measured by the SPM intelligence test and the free throw test. Data were analyzed with the product-moment correlation formula at the significance level $>$ rtable $=\mathbf{0 . 3 8 8}$ and $t_{\text {count }}=6.132>1,706 t_{\text {table }}$.
\end{abstract}

Keywords - Intellectual Intelligence, Shooting Ability

\section{INTRODUCTION}

Basketball is a big ball game that is easily understood by various ages and is a sport that is fun, educational, and healthy. Besides basketball including in sports with the characteristics of mutual attack and has a fast tempo game. Thus, this sport is in need of good cognitive, affective, and psychomotor factors. In the Padang State University Laboratory Development High School, basketball is a sport that is popular in extracurricular activities. This is because every time they compete at least SMA Negeri Padang University Laboratory Development always gets the top 3 of each race. Like the championship held in March 2017, the State University of Padang's High School Development Laboratory got an achievement by winning the basketball tournament in West Sumatra held by one of the high schools in Pariaman district, Lubuk Alung. However, the crest occurred during the DBL championship in the same year, UNP Lab Development High School experienced a decline in performance, where the basketball team only got Runner Up for the women's team and the men's team suffered defeat at the beginning of its match so that the men's team was killed in the DBL championship, this makes the goal to be a champion in every championship not achieved. Based on preliminary observations made at the UNP Labolatorium Development High School, the authors found that there were some students who still had poor concentration and still needed a relatively long time in the problem solving process encountered during the teaching and learning process. This shows that there are students who have poor intellectual intelligence. The alleged shooting ability is not optimal yet, it can be seen from the success of shooting done in the learning of basketball that is still not good. In addition, the explosive power of students' leg muscles when jumping and eye and hand coordination when shooting or passing is not optimal

When shooting, players are required to have good motor skills so that the opportunity to put the ball into the ring is getting bigger, motor skills are divided into two, namely fine motor and gross motor, fine motor is the ability to move using smooth muscles (small muscles) while motor rough is activity by using large muscles which include locomotor, non-locomotor, and manipulative basic motion. Shooting itself involves gross motor skills, because in practice it uses large muscles. In theory motor skills coordinate with the brain so that it greatly affects cognitive. Motor development will be in line with cognitive development. Revealed that cognitive development and motor development are constantly interacting, cognitive development depends more strongly on intellectual abilities in the process of interaction [1].

Shooting success is part of an effort to win the game of basketball. To be able to put the ball in the opponent's ring, not just shoot basketball in vain. Many people interpret that the ability of shooting requires flexibility, strength, and coordination. But there are also supporting factors that intellectual intelligence (IQ) also plays an important role when shooting, because people who have high IQ levels certainly have better motor skills, tend to be able to think fast and can make decisions well, and if someone having a good intellectual level will affect motor skills so that shooting will be better than people who have low IQ levels. Every person has a different level of intelligence. Usually a person's intelligence level can be measured by doing an IQ test. In general IQ is used to explain the nature of the mind which includes a number of abilities, such as the ability to reason, plan, solve problems, think abstractly, understand ideas, use language, and learn. so IQ is very important role for humans. 
Like other sports, basketball also has basic skills that must be mastered by players, some individual skills such as shooting, passing, dribble, and rebounding, and teamwork to attack or defend is a prerequisite for success in playing this sport [2]. These techniques become very important in basketball and must be mastered by players. One of the basic needs in basketball is shooting or shooting. As explained [3] that the most important skill in basketball is the ability to shoot or shoot the ball into the basket. To score a player must think and consider well from the situation in the field.

The problem regarding the factors that affect the success of shooting in basketball which is considered important to be investigated is the level of intellectual intelligence. This factor is considered important to be investigated so that researchers raise the problem of research that is seen from the ability to shoot in basketball, and is associated with the level of intellectual intelligence [4]. Therefore, the authors are interested in researching the relationship between the Level of Intellectual Intelligence and the Capability of Free Throw Shooting for Students who take Extracurricular Basketball High School Laboratory Development in Universitas Negeri Padang.

\section{RESEARCH METHODOLOGY}

This research uses quantitative research type with descriptive correlation method which aims to reveal how the Relationship between Intellectual Intelligence Level and High School Basketball Shooting Ability in Laboratory Development in Padang State University. The time of this research was on 09-12 August 2018. The population in this study were all extracurricular basketball students in the Padang State University Laboratory. Development Senior High School, totaling 26 people. Samples were taken using a total sampling technique because of the relatively small population, the population was sampled as a whole, namely 26 students. The type of data used is primary and secondary data. The data collection techniques in this study are using the SPM Intelligence Test and Shooting Free Throw Test.

\section{RESULTS}

\section{A. Description of Research Data}

The variable in this study is the Relationship of Intellectual Intelligence Level with the Capability of Shooting Free Throw on Students who take Extracurricular Basketball High School Development Laboratory State University of Padang.

Research data processing is presented sequentially as follows:

1) Level of Intellectual Intelligence

Descriptive analysis of the Intellectual Intelligence Level of research respondents, the mean count $=106.1$, standard deviation $=11.6$, minimum value $=90$ and maximum $=$ 133. Data obtained from the results of the Intellectual Intelligence Test of 26 responsive people. For more details, see table 5 as follows:
Table 1. Intellectual Intelligence Level Frequency Distribution

\begin{tabular}{|c|c|c|c|}
\hline IQ Score & Classification & $\mathrm{Fa}$ & $\mathrm{Fr}(\%)$ \\
\hline$\geq 130$ & Very superior & 1 & 3,85 \\
\hline $120-129$ & Superior & 2 & 7,69 \\
\hline $110-119$ & Above average & 7 & 26,92 \\
\hline $90-109$ & Average & 16 & 61,54 \\
\hline $80-89$ & Below average & 0 & 0,00 \\
\hline $70-79$ & Weak boundary & 0 & 0,00 \\
\hline$\leq 69$ & Mentally weak & 0 & 0,00 \\
\hline \multicolumn{2}{|c|}{ Total } & $\mathbf{2 6}$ & $\mathbf{1 0 0}$ \\
\hline
\end{tabular}

Based on the frequency distribution table above of 26 samples, 1 person $(3.85 \%)$ has 2 people $(7.69 \%)$ has a superior classification of intellectual intelligence, 7 people $(26.92 \%)$ has a classification intelligence level above the average on average, 16 people $(61.54 \%)$ have an average level of intellectual intelligence classification, and 0 people / no $(0 \%)$ have a level of intellectual intelligence classification below the average, weak limits, and mental weakness.

2) Ability Shooting

Descriptive analysis of the results of the Shooting Capability of research respondents, obtained a mean $($ mean $)=7.5$, standard deviation $=1.2$, minimum value $=$ 5 and maximum $=9$. For more details, see in table 6 as follows:

Table 2. Frequency Distribution of Shooting Capabilities

\begin{tabular}{|c|c|c|}
\hline Score & Fa & Fr (\%) \\
\hline 5 & 2 & 7.7 \\
\hline 6 & 4 & 15.4 \\
\hline 7 & 3 & 11.5 \\
\hline 8 & 12 & 46.2 \\
\hline 9 & 5 & 19.2 \\
\hline Total & $\mathbf{2 6}$ & $\mathbf{1 0 0}$ \\
\hline
\end{tabular}

Based on the frequency distribution table above of 26 samples, 2 people $(7.7 \%)$ have a shooting ability with a score of 5,4 people $(15.4 \%)$ have a shooting ability with a score of 6,3 people $(11.5 \%)$ have a shooting ability with a score of 7,12 people $(46.2 \%)$ have the ability to shoot with a score of 8 , and $5(19.2 \%)$ have the ability to shoot with a score of 9 .

3) Testing Requirements Analysis

B. Normality Test

The variable normality test uses the liliefors test with a Ltable of 0.161 based on the number of samples $(\mathrm{N}$ $=26$ ) in the critical value table of the liliefors test and the significance level of $0.05 \alpha$, indicating that the data is normally distributed. Complete results of the Liliefors test can be seen in the following table: 
Table 3. Research Data Normality Test

\begin{tabular}{|l|c|c|c|c|}
\hline \multicolumn{1}{|c|}{ Variable } & N & Lo & Ltabel & Ket \\
\hline $\begin{array}{l}\text { Level of Intellectual } \\
\text { Intelligence }\end{array}$ & 26 & 0.1100 & \multirow{2}{*}{0.161} & Normal \\
\cline { 1 - 3 } Shooting ability & 26 & 0.1597 & & Normal \\
\hline
\end{tabular}

\section{Hypothesis Testing}

Hypothesis testing on the relationship between the level of Intellectual Intelligence (X) with Shooting Ability (Y). The statistical test used is the product moment correlation analysis at the significance level of $0.05 \alpha$. The analysis shows that the level of Intellectual Intelligence has a significant relationship with Shooting Ability. For more details, see the correlation test Appendix.

The analysis shows that the Intellectual Intelligence Level (X) has a significant relationship with Shooting Ability. The result of product moment correlation analysis, the research data can be read that the relationship (correlation) of motor ability with the learning outcomes of physical education is $r$ count 0.775 > $\mathrm{r}$ table 0.388 , meaning that the relationship between the level of intellectual intelligence is strong and unidirectional. With a tcount of 6.132> 1.706. Thus the proposed work hypothesis (Ha) can be accepted.

\section{DISCUSSION}

Calculation of correlation between Intellectual Intelligence Level (X) with Shooting Ability (Y) using the product moment correlation formula. Testing criteria if $r$ count $>r$ table, then there is a significant relationship and vice versa. From the results of the calculation of the correlation between the Level of Intellectual Intelligence (X) with Shooting Ability (Y) obtained rcount 0.775> rtable 0.388 at a significant level $\alpha=0.05$, thus the better the level of one's intellectual intelligence, the better the results of shooting ability. From the results of the above analysis it can be concluded that there is a significant relationship between the level of intellectual intelligence with shooting ability. It can be seen from the relationship of the two variables of $60 \%$, and the average IQ in this study is 106.1 (average) and shooting ability 7, 5 To get better shooting skills, the level of intellectual intelligence of students must be increased through exercises that contain intelligence on an ongoing basis.

From all of that, there are other factors beyond intellectual intelligence of $40 \%$, which is assumed from the leg muscle explosive power, eye and hand coordination, wrist flexion and many others.

Here can be seen from the results of research that Raifanda Yuko Arrafi who has the highest intellectual intelligence of 133 (Very superiuor) can do shooting with a shooting score of 8 , with a pretty good score so it can be seen that the relationship of this intelligence is very influential when doing free shooting throw.

. other case with Dhivo Pramudya who has an intellectual intelligence of 107 with an average classification capable of getting a shooting score of 9 , it can be seen that there are other relationships besides intelligence that make the shooting score very good, this is where the relationship between factors such as explosive power is seen. leg muscles, eye and hand coordination and wrist flexion are factors other than intellectual intelligence.

[5] Intellectual which means a person's thoughts and abilities in digesting and analyzing intelligence level based on knowledge that can be seen in everyday life when someone works and thinks. Whether or not fast and resolved or not a problem depends on the ability of intelligence. Judging from his intellectuals. Usually we judge and say smart, reasoned and clear-minded based on science, who have high intelligence. From this we can see a clear relationship between intelligence with shooting in a basketball game, where athletes must be able to think clearly and wisely in making decisions.

This becomes the basis on which the athlete's ability to digest the situation in a match makes the athlete have to think of ideas or strategies quickly and accurately, with this picture can be seen the relationship of intelligence when playing basketball.

it can be concluded that intelligence intelligence is the ability to process, master and process it and then apply it in the face of a problem. It can be seen through these factors that make the foundation of the relationship between intelligence and shooting very significant. shooting is a basic technique in basketball which aims to increase the score in a game, and with this shooting a team can determine the victory in a match.

Based on the explanation above it is clear that the level of intellectual intelligence has a relationship to shooting ability, especially students in the SMA Negeri Padang University Development Laboratory. For this reason, the Penjasorkes teacher must give more direction which is constructive in the intellectual field in the learning process, especially in the basketball extracurricular process, so that they have a high intellectual level. This must also be supported by good nutrition, so that he is physically strong in doing sports and sports activities.

\section{CONCLUSION}

Based on the findings and discussion in this study, it can be concluded that there is a Relationship between Intellectual Intelligence Level and Shooting Ability in High School Basketball Extracurricular Students in Laboratory Development in Padang State University. and $\mathrm{t}=6132>1,706$ table.

Based on the conclusions above, the writer can provide suggestions that can help overcome problems encountered in improving shooting capabilities, namely:

1. Penjasorkes Teachers are advised to apply and pay attention to aspects of motor skills in carrying out the Penjasorkes learning process especially extracurricular basketball learning in addition to other factors that contribute to improving basketball shooting abilities.

2. It is expected that the basketball extracurricular trainer will make a training method that can increase intellectual intelligence.

3. It is expected that parents of students pay more attention to their child's nutritional intake so that the child can participate in all activities to the maximum. 


\section{REFERENCES}

[1] R. Yenes. "Pengaruh Daya Ledak Otot Tungkai dan Keseimbangan Terhadap Kemampuan Jump Shot Atlet Bolabasket FIK UNP”. J. Performa Olahraga, Vol. 3 No.02, pp119-119. March 2018.

[2] Anang Idris, Madri. "Pengaruh Latihan Ballhanding Hight Frekuensi dan Barrier Training terhadap Kemampuan Dribbling Bola Basket. J. Pendidikan Olahraga. Vol. 2 No 2. pp.16-18. September. 2019.

[3] Amber, Vic. "Basket Ball "The Basics For Coach And Player". Bandung: Cv. Pionir Jaya. 2005. pp.23-34.

[4] Feby Ilham, Tjung Hauw Sin, R. Yenes. "Tinjauan Kondisi Fisik Atlet Bolabasket SMA Negeri 1 Sungai Tarab Kabupaten Tanah Datar". J. Pendidikan Olahraga. Vol. 2 No 1. pp.57-62. January. 2019.

[5] Deswandi, Syafruddin, Khairuddin. "Studi Kemampuan Motorik Siswa Sekolah Dasar Negeri 2 Air Tawar Timur Kecamatan Padang Utara Kota Padang”. J. Menssana. Vol. 3 No 2. pp. 81-92. November. 2018 